\title{
Limitations of the Theory of a Corporate Entity in California
}

THE idea of a corporation as an entity distinct from its members has come down to us from the time of the Romans. There is not yet, however, any unanimity of opinion on the question whether that entity is a fact or a fiction. ${ }^{2}$ But the fact that a distinct corporate entity is everywhere conceded to exist, made it necessary as corporations gradually became more numerous for the courts to consider whether or not they should in all cases be bound by it, or whether they could under certain circumstances look through the corporate cloak to the actual stockholders.

The fact that corporations were coming to be frequently used for the perpetration of fraud, led the courts in recent years to disregard the corporate entity for the purpose of protecting the rights of innocent third persons. ${ }^{2}$ This custom has become so common as to evoke an occasional word of protest. Thus Mr. Justice Holmes in the case of Donnell v. Herring-Hall-Marvin Safe Company ${ }^{3}$ said:

"Philosophy may have gained by the attempts in recent years to look through the fiction to the fact and to generalize corporations, partnerships and other groups into a single conception. But to generalize is to omit, and in this instance to omit one characteristic of the complete corporation, as called into being under modern statutes, that is most important in business and law. A leading purpose of such statutes and of those who act under them is to interpose a nonconductor though which, in matters of contract, it is impossible to see the men behind."

It may be of value to follow the growth in California of the doctrine that under certain circumstances the courts will look

1 Compare 1 Morawetz on Private Corporations, $\$ 227$ with 24

Harvard Law Review 253.

2 Cook on Corporations, 7th Ed. $\$ 663-4$.

3208 U. S. 267, 273, 28 Sup. Ct. Rep. 288, 52 I. Ed. 481. 
through the corporate cloak, and note the extent to which the doctrine obtains today.

The existence of a corporate entity distinct from the stockholders is, of course, well settled in this state. Thus we are told that,"

"The corporation is a distinct individual, holding the legal title to the property in trust for the benefit of shareholders, who are the beneficiaries having the equitable interest."

Also that : ${ }^{5}$

"The bare fact that a man holds 'shares in the capital stock' of a corporation gives him no legal title to the property of the corporation. That remains in the corporation and not in the shareholders."

Hence it follows that the stockholders of a corporation have no power as such to authorize the sale of the corporate property, or to sell the same either when collectively assembled as such in a stockholders' meeting, or when acting individually."

The California Suprene Court, quoting from a New York decision, has said that the right which a shareholder in a corporation has, by reason of his ownership of shares,"

"is a right to participate according to the amount of his stock in the surplus profits of the corporation on a division, and ultimately on its dissolution, in the assets remaining after payment of its debts."

At an early date the Supreme Court of California held that under certain circuunstances a corporation might be regarded as the "mere agency of the associates." In the case of Chater $\mathbf{r}$. San Francisco Sugar Refining Company," decided in I86I, it appears that the three incorporators had agreed prior to the incorporation upon the equal division of the stock of the corporation; the corporation having been organized, it proceeded to carry on the business for which it was formed, but no stock was issued to one of the contracting parties. He brought suit against his associates and the corporation, asking for specific performance of the contract, whereby he was to have one-third of the stock.

4 Miners' Ditch Company v. Zellerbach (1869), 37 Cal. 543, 591, 99 Am. Dec. 300.

${ }^{5}$ Kohl v. Lilienthal (1889), 81 Cal. 378, 385, 20 Pac. 401, 22 Pac. 689.

- Gashwiler v. Willis (1867), 33 Cal. 11, 91 Am. Dec. 607.

7 Richter v. Henningsan (1895), 110 Cal. 530, 534, 42 Pac. 1077.

\& (1861), 19 Cal. 219. 
The objection was urged that the corporation was not bound by the contract, not having been a party to it, nor having subsequently adopted it. The Supreme Court in affirming a judgment for the plaintiff stated as its premise that,

"The corporation is little more, under our laws, than a joint stock company under the English laws; indeed, in its true nature more nearly resembling a limited partnership under special articles than a corporation at common law."

Hence, said the court:

"The truth is, the corporation, under our system, following such an agreement, would be the mere agency of the associates created for the sake of convenience in carrying out the agreement, as between those who made the bargain, the different characters or forms in which or by which the bargain was made, and the order in which the several parts of it were executed, making no substantial difference in the obligation."

The enunciation of this far reaching doctrine was entirely unnecessary to the decision of the case, since, as the court went on to point out, the business of the corporation had been carried on for a long time with reference to the terms of the agreement of the incorporators, so that "if anything could be, this was an adoption by the corporation of these terms." This last ground afforded ample justification for the decision of the court, as was in fact subsequently recognized. ${ }^{\circ}$

The comparison made by the court of a corporation under our laws to a joint stock company under the English laws was too broad a generalization. The idea in the mind of the court had been more accurately stated in an earlier decision, to the effect that, ${ }^{10}$

"the members of a corporation, who are answerable personally for the corporate debts and liabilities, stand in the same position in relation to the creditors of the corporation, as if they were conducting their business as a common partnership."

But the doctrime of the Chater case afforded too easy a solution of difficult questions to be permitted to sleep. In the case of Shorb v. Beaudry, ${ }^{11}$ in which it appears that the incorporators

- Scadden Flat G. M. Co. v. Scadden (1898), 121 Cal. 33, 38, 53 Pac. 440.

${ }_{10}$ Mokelumne Hill Canal Company v. Woodbury (1859), $14 \mathrm{Cal} .265$. 11 (1880), 56 Cal. 446. 
of a company had disagreed in regard to the performance of a contract made by them prior to the organization of the corporation, the court stated that the purpose of the incorporators to form a corporation to act as a mere agency for more conveniently carrying out the agreements between the incorporators, was sufficiently apparent. The court declared that,

"Substantial justice can be administered in this case by treating the parties in the light of their agreements between themselves, independently of their incorporation, and in no other way that we have been able to discover can this be done."

The court in support of its decision quoted from the Chater case to the effect that under certain circumstances the corporation could be regarded as the mere agency of the associates. An accounting had been had in the lower court, and the Supreme Court accordingly directed that the capital stock of the corporation should be treated as partnership assets and sold, the proceeds to be divided between the incorporators in proportion to the amounts owing to each of them.

The doctrine of this and the preceding case was repudiated in a comparatively recent decision by the Court of Errors and Appeals of New Jersey. ${ }^{12}$ The California cases were not mentioned, however, by the court. It was argued that the stockholders of the corporation "were really copartners doing business in a corporate form for their own convenience." The court said in response thereto:

"We cannot subscribe to any such doctrine. An agreement or course of dealing by which corporations are organized for the purpose of using them merely as agencies or instrumentalities or forms in the conduct of a copartnership or joint business, and by the consent of the parties in interest to be independent of statutory control, cannot be recognized, enforced, or perpetuated by the Court of Chancery in this state. It is fundamental that, no matter how the shares of stock are held, the corporation itself is an entity wholly separate and distinct from the individuals who compose and control it. . . . The law never contemplated that persons engaged in business as partners may incorporate, with intent to obtain the advantages and immunities of a corporate form, and then, Proteus-like, become at will a copartnership

${ }^{12}$ Jackson v. Hooper (1910), 76 N. J. Eq. 592, 75 Atl. 568. 
or a corporation, as the exigencies or purposes of their joint enterprise may from time to time require. The policy of the law is to the contrary. If the parties have the rights of partners, they have the duties and liabilities imposed by law, and are responsible in solido to all creditors. If they adopt the corporate form, with the corporate shield extended over them to protect them against personal liability, they cease to be partners, and have only the rights, duties, and obligations of stockholders. They cannot be partners inter sese and a corporation as to the rest of the world. Furthermore, upon grounds of public policy, the doctrine contended for cannot be tolerated, as it renders nugatory and void the authority of the Legislature-a co-ordinate branch of the governmentestablished by the Constitution, in respect to the creation, supervision, and winding up of corporations."

The doctrine of the Chater case and of Shorb v. Beaudry has, however, been followed in California, except in those cases where it was clearly inapplicable. ${ }^{13}$

In the case of Kohl v. Lilienthal, ${ }^{14}$ it was held in a department decision that an agreement by the majority of the stockholders of two corporations that the property of the corporations should be conveyed to a third corporation in exchange for stock in the third corporation, the stock so received to be divided among the stockholders of the two original corporations, was valid. The court argued that section 309 of the Civil Code prohibiting the payment to the stockholders of a corporation of any part of the capital stock, except as expressly authorized by that section, was directed against the trustees and was intended to protect the stockholders and creditors of the corporation against improvident action on the part of the trustees. Hence, the court said that, since it appeared that injury would not result either to the stockholders, or to the creditors of the corporations concerned, no valid objection could be made to the agreement. The court cited the case of Chater v. San Francisco Sugar Refining Company as

"having asserted that stockholders have a right to preserve their just rights of property in consonance with contracts which they may have made, notwithstanding the intervention of corporate agencies, which claim the property for themselves."

13 Cornell v. Corbin (1883), 64 Cal. 197, 30 Pac. 629; Hunt v. Davis (1901), 135 Cal. 31, 66 Pac. 957.

14 (1889), 81 Cal. 378, 20 Pac. 401, 22 Pac. 689. 
But upon rehearing, in bank, it was held that the agreement was invalid. The court said that even if the stockholders of the two corporations had unanimously assented to the terms of the agreement, it could not be sustained. In answer to the contention that section 309 was merely a prohibition against the division of the capital stock by the directors, the court held that the inhibition ran against the directors only because they are, under the law, managers of the business of the corporation and that what they cannot do, as a general rule, the stockholders cannot do.

In the Chater case the court was careful to limit the rule there enunciated, saying that "as between those who made the bargain" for the organization of a corporation, such corporation could be regarded as their agent. In the case of Behlow $v$. Fischer, ${ }^{15}$ the court had occasion to consider the right of certain incorporators to maintain an action for an accounting brought against one of their number, and also against certain of his assignees. The court held that there was a misjoinder of parties defendant. Said the court:

"If it be conceded that the original partners hereto formed a corporation for carrying out the object of their partnership, and that others who succeeded to their interests are bound by an agreement of that character which they subscribed to, or of which they had notice, there is no averment in the complaint which sustains this theory. . . . . In the absence of any averment that there was such an agreement as we have above referred to, they must be regarded merely as stockholders in the corporation who have purchased their stock upon the faith that the assets of the corporation were its property, and that the stock held by them was capable of transfer and purchase like the stock of any other corporation."

Not only may a corporation be regarded as a mere agency of the incorporators so long as they are the only parties interested, but, according to the District Court of Appeal, one corporation may be held to be the mere agency of another corporation.

In the case of Kelly v. Ning Yung Benevolent Association, ${ }^{16}$ the plaintiff sued to recover for services alleged to have been rendered by his assignor to the defendant corporation. The defendant contended that the services were rendered to a separate corporation. It was shown on the trial that the separate corpo- 
ration referred to had been organized by certain of the stockholders of the defendant for the purpose of acquiring and holding certain land for burial purposes, because of the lack of power under the charter of the defendant so to do. Under all of the evidence the District Court of Appeal held that ${ }^{17}$

"The jury was authorized to find that the cemetery corporation was merely an agency or instrumentality adopted by the defendant for carrying out the purposes of its incorporation, and that the defendant was liable for whatever services were rendered by $\mathrm{Mr}$. Nagle at its instance or request in reference to or connected with said auxiliary corporation."

We coine now to another class of cases somewhat akin to those just discussed, in which the courts likewise hold that they inay look beyond the corporate entity when they believe that justice can better be subserved by so doing. The cases to be considered in this connection are those involving the rights and obligations of what are frequently termed "one-man corporations."18

The first case in this state in which a corporation of this character was involved is Relley v. Campbell.19 The action was brought to foreclose a mortgage. The mortgage appeared to have been executed by one Patrick Campbell and the New Blue Point Mining Company, a corporation. The complaint contained averments tending to show that the corporation sued was, as to the property involved, but another name for Patrick Campbell. It appeared that the mortgage was defective as to the corporation by reason of having been authorized at a meeting of the directors at which but part were present, no notice having been sent to all of their number. Plamtiff contended that since Campbell was the sole owner of the property and of the corporate stock, and since Campbell had represented that the mortgage was regularly executed by the corporation, he and his corporate double should be estopped to deny the validity of the mortgage. The court held that an action "might be sustained upon such a theory, if there was evidence to support it." The court decided, however, that there was not enough competent evidence to support the allega-

- 17 Although the court cites the cases heretofore considered by us as authorities for the decision, there is some question whether the decision could not have been more logically based upon the ground next to be considered.

${ }_{18}$ Machen on Corporations, Chap. XVII.

19 (1901), 134 Cal. 175, 66 Pac. 220. 
tions of the complaint and reversed the judgment of the lower court in so far as the corporation had thereby been held liable.

This dictum was relied on by the District Court of Appeal in the case of Rutz v. Obear. ${ }^{20}$ Plaintiff sued for services alleged to have been rendered for and at the instance of the defendant. The defendant contended that the services had been rendered for a corporation in which he was merely a stockholder. The court in upholding the judgment in favor of the defendant said that the case of Relley v. Campbell,

"is authority for the statement that where one individual owns all of the stock of a corporation, the same is but the corporate double of the owner of the stock, and such proof destroys the separate entity of the corporation, and in such event the statements and admissions of the sole owner of the stock may be received as establishing facts from which an estoppel might arise as to the corporation."

In the case of Deming v. Maas, ${ }^{21}$ the doctrine was extended to a case where not all, but practically all of the stock of a corporation was owned by one individual. In that case a bond had been executed by Louis Maas and "Jos. Herrscher \& Company" conditioned that the principal named therein should pay certain sums as rent in accordance with the terms of a lease taken by him. The terms of the lease were subsequently changed. The agreement modifying the terms of the lease was subscribed "For Jos. Herrscher \& Company, Inc., Jos. Herrscher." Upon a default occurring in the payment of the rent, the lessor sued Jos. Herrscher individually. The defendant denied that he individually had ever signed the undertaking, or that he had ever.assented to the modification of the lease. The lower court found,

"that Jos. Herrscher \& Company, Inc. was the individual trade name of Jos. Herrscher; that it was mutually understood between Herrscher and the plaintiff that Herrscher alone was intended to be designated by such name."

The court also found that the modification of the lease was at the express request of Herrscher personally. It was also found that of the one thousand shares constituting the authorized capital stock of Jos. Herrscher \& Company, all but five shares were owned by Herrscher, the five shares mentioned being owned by 
directors for the purpose of qualifying them. The District Court of Appeal held that the evidence introduced was ample to support the findings of the lower court. It was here said:

"The proof shows that Herrscher was himself practically the corporation. . . . Under these circumstances, the subscription of the corporation's name to the writing effecting the alteration in the terms of the lease, was at one and the same time both the act of the corporation and his act as an individual. Being practically owner of all the stock, he was virtually the corporation itself, or, as the cases put it, the corporation was "his corporate double." "

This principle is also illustrated in the case of Finnell v. Finnel1.22 It appears from the decision that John Finnell, Sr., the purchaser of certain real property, had given his promissory note in payment of the purchase price thereof. After the contract of purchase had been executed, a creditor of the vendee induced the latter to organize a corporation, the Finnell Land Company, and to transfer the land mentioned, together with certain other property, to that corporation, in consideration of the issue to John Finnell of about two-thirds of the capital stock of the corporation, the remaining one-third going to the creditor mentioned, nominal amounts of stock being issued to the sons of the original vendee. The lower court found that the original vendee was the beneficial and equitable owner of all of the stock issued, and also found that the directors of the corporation knew at the time of the purchase by it of the land involved, that it had not been paid for. In an action by the original vendor to foreclose his vendor's lien, the Supreme Court said in affirming a judgment for the plaintiff:

"John Finnell, Sr., with the aid of dummy directors and stockholders incorporated himself, and conveyed the land to himself so incorporated. . . . We know of no theory upon which it may be held that the Finnell Land Company, constituted as it was, did not take with notice of plaintiff's right."

The most recent decision dealing with this question is Atkinson v. Western Development Syndicate. ${ }^{23}$. The plaintiff in that case had asked to have certain conveyances made by a corporation to another corporation whose incorporators, stockholders and 
directors were in the main the same persons who constituted the stockholders and directors of the vendor, set aside on the grounds (I) that the two corporations were really the same, and (2) that the conveyances were made to defraud the plaintiff. The lower court found against the plaintiff on both contentions and gave judgment for the plaintiff, which was affirmed by the Supreme Court. In answer to the contention that the two corporations were substantially the same, the court said that while the identity of the stockholders and directors furnished soine support to the claim, other circumstances, such as the different character of the busmess carried on by the two corporations, justified a different conclusion.

The last class of cases in which the doctrime under discussion is involved is that involving fraud. Frequently cases of fraudulent conveyances made by a vendor to a corporation organized by him are cited as illustrative of this phase of the doctrine. ${ }^{24}$ Obviously, resort to this doctrine is not necessary in cases of that character. If a conveyance is made for the purpose of defrauding creditors, it is as to such creditors, void, whether the conveyance is made by the vendor to an individual or to a corporation organized by him. $^{25}$ There is no necessity for looking through the corporate veil in such a case.

The rule in the case of such conveyances to corporations was stated in the case of Atkinson v. Western Development Syndicate. ${ }^{28}$ In that case the court said:

"It is well settled that if the stockholders of a corporation organize another corporation and transfer all of the assets of the former to the latter, without paying the debts of the former, the transfer, irrespective of the actual intention of the parties, constitutes a fraud on the creditors of the old corporation, and the new corporation is liable in equity for the debts of the old to the extent of the assets received."

The principle under discussion came up in a somewhat novel manner in the case of Blanc v. Payınaster Mining Company. ${ }^{27}$ In that case it appears that a corporation sold all of its property to one of its officers for the purpose of defrauding its creditors. The

2412 Columbia Law Review, 496.

25 Cal. Civ. Code, §§ 3439, 3442.

26 (1915), 170 Cal. 503, 150 Pac. 360, citing 2 Clark \& Marshall Private Corporations, 342 , i.

27 (1892), 95 Cal. 524, 30 Pac. 765. 
officer to whom the property was conveyed organized a new corporation composed of the principal officers and stockholders of the old corporation to which the property was again sold. In an action by a creditor of the old corporation to have the conveyances declared void, judgment was entered in his favor by the trial court, which was upheld on appeal. The defendant contended that the judgment against the old corporation, being void for lack of proper service, the action, in so far as it was sought thereby to vacate the conveyances, could not be maintained. The ground of contention was that a creditor must first have recovered a valid judgment against his debtor and have an execution returned unsatisfied before he is entitled to resort to an equitable action to reach property fraudulently conveyed. The court, holding that the identity of the two corporations made such action unnecessary in the case before it, said:

"We think, upon this state of facts, a court of equity will regard the defendant as a mere continuation of the former corporation under a different name, and will hold it liable for the indebtedness of the Esperanza Coinpany, at least to the extent of the value of the property which it received from it without consideration, and under the circumstances stated. Nouninally, the two corporations may be different, but as viewed in equity, they are the same, and the plaintiff is not prevented from asserting such identity in fact."

In the case of Higgins v. California Petroleum Company ${ }^{28}$ it appears that an attempt was made by a lessee corporation to evade liability on a lease by a conveyance of the leased premises to another corporation organized by it. The Supreme Court apheld a judgment for the plaintiff, stating that the evidence strongly suggested that,

"the main, and perhaps the sole, purpose of this organization, was to evade the obligations of this lease. . . . . The old company was to continue to be the lessee, but was to do no mining; while it was to permit the new company, its alter ego, to mine without any responsibility therefor. We therefore think that the court below was justified in holding that the new company was only the old one under another name; and that being so, it is plain that their responsibility to Higgins (the lessor) was not impaired by this merely nominal transfer."

28 (1898), 122 Cal. 373, 376, 55 Pac. 155. See same case on subsequent appeal, reported (1905), 147 Cal. 363, 81 Pac. 1070. 
Although the lower court had not found that there was any actual fraud in the transaction, the Supreme Court held that as against the holder of an existing obligation, it was constructively fraudulent as a matter of law.

The District Court of Appeal refused, however, to apply the doctrine of these cases in a decision handed down in 1914. In that case, ${ }^{29}$ the argument of the plaintiff, which he contended had been laid down in the cases just discussed, as well as by courts of other jurisdictions, was that,

"a corporation cannot evade its just debts, avoid the obligations of its contracts, or be made immune against tortious conduct, by merely changing its name and assuming the outward form of a new corporation."

The District Court of Appeal did not dispute the correctness of the general doctrine relied upon, but, as it explained,

"The doctrine declared in those cases, as we understand it, is merely to the effect that where it is affirmatively alleged, or the pleaded circumstances show, that in truth the creation of a new corporation is but the continuation under a new charter of a pre-existing corporation, the new corporation will be held liable for the debts of the old corporation; and where all of the assets and property of the old corporation have been transferred to the new corporation, such assets and property may be followed by a creditor of the old corporation, and be rightfully subjected to the satisfaction of a judgment obtained against the old corporation."

As the court pointed out, plaintiff's complaint was defective in that it merely alleged a conveyance by a foreign corporation of part of its assets to a California corporation having the same name, in exchange for stock in the California corporation, and did not allege any intent on the part of those interested to defraud the plaintiff. The court properly held that:

"The mere fact that separately created and existing corporations bear the same name and deal in the same commodities, will not suffice even if the officers and stockholders of each corporation be the same, to create a merger of corporate capacity, identity and liability."

Hence the court held that the transfer by a foreign corporation of its agency from a real to an artificial person of its own creation

${ }^{29}$ Koch v. Speedwell Motor Car Co. (1914), 24 Cal. App. 123, 125, 126, 127, 140 Pac. 598. 
"would not in and of itself operate to fasten the legal liability for its pre-existing obligations upon the shoulders of its corporate agent."

Even though one of the principal purposes of our incorporation laws may be, as Mr. Justice Holmes says, to authorize the creation of a "non-conductor" through which it is impossible to see the man behind it, it is of greater importance to see to it that valid agreements are carried out, and that frauds are not perpetrated. It may confidently be asserted that our courts have not in the cases considered, infringed upon the doctrine of a corporate entity further than justice required under the facts involved.

Robert L. McWilliams.

San Francisco, California. 